\title{
Advances in femtosecond laser technology
}

This article was published in the following Dove Press journal:

Clinical Ophthalmology

19 April 2016

Number of times this article has been viewed

\author{
Thais Pinheiro Callou \\ Renato Garcia \\ Adriana Mukai \\ Natalia T Giacomin \\ Rodrigo Guimarães de \\ Souza \\ Samir J Bechara
}

Department of Ophthalmology, University of Sao Paulo, Sao Paulo, Brazil
Correspondence: Thais Pinheiro Callou Department of Ophthalmology, University of Sao Paulo, Instituto Central, 255 Eneas de Carvalho Aguiar AV, Sao Paulo, Brazil

Email thaiscallou@hotmail.com
Abstract: Femtosecond laser technology has become widely adopted by ophthalmic surgeons. The purpose of this study is to discuss applications and advantages of femtosecond lasers over traditional manual techniques, and related unique complications in cataract surgery and corneal refractive surgical procedures, including: LASIK flap creation, intracorneal ring segment implantation, presbyopic treatments, keratoplasty, astigmatic keratotomy, and intrastromal lenticule procedures.

Keywords: laser therapy, refractive surgical procedures, intracorneal ring, laser in situ keratomileusis, keratoplasty, presbyopia, cataract extraction, astigmatism surgery

\section{Introduction}

The femtosecond (FS) laser operates in the infrared range (wavelength: 1,053 nm) and uses ultrafast pulses with a duration of $100 \mathrm{fs}$ (10-15 seconds). Like neodymium-doped yttrium aluminum garnet laser, FS laser is solid and capable of causing disruption in stromal tissue through the principle of photoionization, resulting in the rapid formation of a cloud of free electrons and ionized molecules. Small volumes of tissue are vaporized, with the formation of cavitation bubbles made up of carbon dioxide and water. This gas is dissipated in the tissue, forming a cleavage plane. ${ }^{1}$

The prototype of the first corneal surgery with FS laser was developed in US in the early 1990s. ${ }^{2}$ In 2001, the first LS laser (Intralase Pulsion) was approved by the US Food and Drug Administration for the creation of corneal lamellae in laser-assisted in situ keratomileusis (LASIK). Improvements in the technology occurred quickly, with the increase in pulse frequency and reduction in the amount of energy released so that only the desired tissue was affected while adjacent areas remained intact, thereby ensuring fewer harmful effects - the main advantage of this method.,

FS laser currently has numerous applications and is no longer restricted to the cornea. The main uses of this method include the flap creation in LASIK surgery, tunneling of the cornea for the implantation of an intrastromal ring, and the creation of corneal incisions and lamellae in lamellar and penetrating keratoplasty. FS laser has also been used for the removal of corneal lenticules for the correction of myopia, presbyopia, natural astigmatism, and post-corneal implant astigmatism. ${ }^{1}$ Lately, FS laser has also been used in phacoemulsification surgery for incisions, fragmentation of the nucleus and capsulorhexis..$^{5-15}$

Commercially available FS laser types include IntraLase (Abbott Medical Optics Inc., Santa Ana, CA, USA), Femtec (20/10 Perfect Vision AG, Heidelberg, Germany) Femto LDV (Ziemer Ophthalmic Systems, Port, Switzerland), VisuMax (Carl Zeiss Meditec AG, Jena, Germany), WaveLight FS200 (Alcon Laboratories, Inc., Fort Worth, TX, USA), LenSx (Alcon Laboratories, Inc.), ${ }^{16}$ Victus (Bausch \& Lomb Incorporated, 
Table I Commercially available femtosecond lasers

\begin{tabular}{|c|c|c|c|c|c|c|c|c|}
\hline Parameter & $\begin{array}{l}\text { Femto } \\
\text { LDV }\end{array}$ & $\begin{array}{l}\text { WaveLight FS } \\
200\end{array}$ & $\begin{array}{l}\text { FemTec } \\
20 / 10\end{array}$ & $\begin{array}{l}\text { IntraLase iFS } \\
\text { I } 50\end{array}$ & $\begin{array}{l}\text { Zeiss } \\
\text { VisuMax }\end{array}$ & Victus & Catalys & Lens X \\
\hline Wavelength (nm) & $\mathrm{I}, 045$ & 1,045 & $\mathrm{I}, 053$ & 1,053 & $\mathrm{I}, 043$ & $1,040 \pm 25$ & $\mathrm{I}, 030$ & $1,030 \pm 5$ \\
\hline Centration & Mechanical & Computer & Mechanical & Computer & Mechanical & Computer & Computer & Computer \\
\hline Visualization of surgery & Virtual & Visual and virtual & Visual & Visual and virtual & Visual & OCT & OCT & OCT \\
\hline Mobile & Yes & No & No & No & No & No & No & No \\
\hline Applanation surface & Planar & Modified Planar & Curved & Planar & Curved & Curved & Curved & Curved \\
\hline
\end{tabular}

Abbreviation: OCT, optical coherence tomography.

Bridgewater, NJ, USA), and Catalys (Abbott Medical Optics Inc., Santa Ana, CA ${ }^{17}$ (Table 1).

\section{LASIK flap creation}

LASIK surgery is widely used in the correction of refractive errors and involves the creation of an anterior lamella, followed by stromal photoablation using an excimer laser. ${ }^{18}$ The creation of this lamella is an important step in the surgical procedure and can be performed by two methods: the mechanical microkeratome and the FS laser microkeratome. ${ }^{19}$ Aiming to improve the predictability of refractive surgery and avoid its complications, the flap creation has been richly studied.

The advantages of FS laser flap creation compared to mechanical microkeratomes include reduced incidence of flap complications, greater surgeon choice of flap diameter, thickness, side-cut angle, hinge position and length, decreased risk of infection, less induction of dry eye, less effect on corneal sensitiviity, increased precision with improved flap safety and thickness predictability, and the ability to cut thinner flaps. ${ }^{20-24}$

LASIK flaps created by FS laser present a significantly lower deviation from the target thickness and are more predictably than flaps created by microkeratome, making LASIK surgery safer and more accurate. ${ }^{25,26}$ Thinner flaps make corneal surgery possible in patients with reduced thickness of the cornea and more severe ametropia and are associated with fewer changes in corneal biomechanics, ${ }^{27}$ thereby reducing the percent of tissue altered (PTA) and the risk of postoperative ectasia. ${ }^{28}$

Chen et al performed a meta-analyses to compare FS laser to mechanical microkeratomes for myopic LASIK and found similar results in regards to safety and efficacy, although FL laser could offer potential advantages in predictability. ${ }^{29}$

LASIK flaps created by FS laser appears to be equivalent in relation to the wavefront analysis and final visual acuity. The FS laser offers advatages over microkeratomes. These include increased precision, a reduced incidence of flap complications, and the ability to cut thinner flaps. The use of the FS laser has made flap creation in laser in situ keratomileusis surgery safer and more predictable.

\section{Intrastromal corneal ring segment (ICRS) implantation}

ICRS implantation has been proposed as an additive surgical procedure for keratoconus correction to delay, if not prevent, the need for corneal grafting. ${ }^{30,31}$ The goal of ICRS implantation is to regularize the front surface of the cornea while maintaining the existing biomechanical status of the underlying stroma. ${ }^{32}$

Manual corneal tunneling for the implantation of an intrastromal ring offers good outcomes, but can result in complications such as epithelial defects, perforation, and segment superficialization and extrusion. ${ }^{33-35}$

Comparing the two techniques, Kubaloglu et al found similar visual and refractive results, but significantly fewer complications with FS laser. ${ }^{36}$ Rabinowitz et al and Carrasquillo et al compared FS laser and mechanical tunnelization in the treatment of ectatic eyes, but observed no differences in visual and refractive outcomes. ${ }^{37,38}$

Despite the overall lower incidence of complications reported for FS laser, Pinero and Alio reported cases of ring migration and extrusion in tunnels made with FS laser, showing that this technique also has drawbacks. ${ }^{39}$

The tunnel created by the FS laser can also be used for procedures combined with crosslinking. Studies revealed that intracorneal riboflavin injection for combined collagen crosslinking and ICRS implantation was safe and may provide more penetration without epithelial removal. ${ }^{40,41}$

Theoretically, compared with mechanical tunnel creation, which is based on surgeon skill, the FS laser-assisted procedure should generate a more accurate stromal dissection with less depth variability, leading to better visual and refractive results. This could lead to a more predictable refractive result. But further studies are required to confirm this theory. ${ }^{37,42}$

\section{Presbyopia treatment}

According to recent estimates, presbyopia is the most common type of refractive error, affecting more than two billion people worldwide. ${ }^{43}$

The FS laser may be used to create intrastromal pockets and provides several different therapies in ophthalmology; 
for example, the MyoRing, a continuous full-ring implant which is implanted into the corneal pocket for the treatment of myopia and keratoconus. Pockets are used for corneal inlays in presbyopia. ${ }^{44}$

The field of refractive surgery has seen a growing interest in the use of corneal implants for the treatment of this condition. Such implants (referred to as inlays) can be inserted using a microkeratome or FS laser, ${ }^{45,46}$ however, the latter provides greater predictability. ${ }^{47}$

Intrastromal FS laser treatment (INTRACOR) using FS laser is another option to correct presbyopia by selectively changing the topographic and refractive characteristics of the central portion of the cornea. This technique was first described in 2009 and makes the cornea multifocal through circular stromal incisions made around the pupil. The cut pattern induces a corneal curvature change with a central steepening with reduced spherical aberrations after surgery. Technolas (Technolas Perfect Vision Gmbh, München, Germany) is the model used for INTRACOR. ${ }^{48,49}$

An advantage of the use of an inlay resides in the fact that, unlike INTRACOR or PrebyLasik, it can be removed if the patient is unable to adapt to it. ${ }^{50}$

Presbyopia correction methods involving FS laser have not yet been extensively evaluated with regard to longterm results, however, this laser function seems to be quite promising.

\section{Astigmatic keratotomy}

The creation of incisions for the correction of astigmatism, either natural or secondary to keratoplasty, trauma, cataract surgery or other causes, constitutes an important use of FS laser. ${ }^{51,52}$

Excimer laser, limbal relaxing incisions, compressive sutures, and wedge excision can be used for the correction of postsurgical astigmatism. ${ }^{53,54}$ However, astigmatic keratectomy is the most common technique. It consists of a circular corneal incision with a diameter smaller than the donor-receptor junction, which can be performed either manually or with FS laser. ${ }^{55}$

Using FS laser, Nubile et al found a reduction in the cylinder from $7.16 \pm 2.70 \mathrm{D}$ in the preoperative period to $2.39 \pm 1.62 \mathrm{D} 6$ months after the procedure in patients who underwent corneal transplantation, in addition to a $58 \%$ reduction in absolute astigmatism observed in the topography. ${ }^{56}$

The manual method can lead to decentration, epithelial defects, abrasions, and perforations. In contrast, FS laser produces more precise and stable cuts and is associated with fewer complications. ${ }^{57,58}$ However, the precision of FS laser technology in creating incisions still needs to be matched with better nomograms for an accurate correction. This technology is still evolving and advanced refinements are currently being developed in the newer generation FS laser devices.

\section{Keratoplasty}

FS laser is currently used in penetrating and lamellar keratoplasty (LK). It provides precise incisions on different planes with minimal harm to adjacent tissues..$^{59,60}$

The use of an FS laser optimizes the LK technique by raising the precision of lamellar dissections and side cuts. This technique also has less risk of microperforations while it is possible to visualize the cornea during lamellar dissection. In theory, the smooth interface should improve visual results. ${ }^{61,62}$

Penetrating keratoplasty performed with a FS laser is capable of creating circular or multiplanar incisions for corneal trephinations for penetrating keratoplasty, which potentially increases graft-host interface surface area, better wound apposition, fit, and stability. ${ }^{63}$ According to Farid et al, it improves residual refractive errors and leads to earlier visual recovery compared to the conventional technique. ${ }^{8}$

Deep anterior LK, which involves the removal of anterior diseased cornea while leaving deeper tissue intact, is becoming a more widely used corneal surgery. Its superiority over penetrating keratoplasty lies in the fact that the donor graft is transplanted devoid of its main antigenic load, the corneal endothelium. ${ }^{64}$ Alio et al, in a recent study, compared the outcomes of deep anterior LK using FS laser and conventional manual technique. FS assisted and manual techniques show comparable visual and refractive outcomes at 1 year after the surgery. ${ }^{65}$

The FS laser represents, at this moment, an excellent choice in order to achieve several goals: good wound apposition, biomechanical stable incision, minimal suture tension, rapid recovery of the wound and vision, and a less invasive surgical procedure that offers the patient the best results in terms of refractive outcomes. ${ }^{66}$

\section{Small incision lenticule extraction}

Small incision lenticule extraction (SMILE) technology is a technology for correcting refractive errors that has become available for intrastromal lenticule cutting and subsequent lenticule extraction. SMILE can be performed with FS Visumax (VisuMax; Carl Zeiss Meditec AG), and seems to affect the biomechanics of the cornea less due to the absence of an extensive cut (as in LASIK surgery) and stromal photoablation. Thus, less stromal tissue is consumed. ${ }^{67}$

A smaller incision also means less nerve damage, with a lower incidence of symptoms of dry eye following refractive 
surgery ${ }^{68}$ According to Dong et al, corneal cell death and inflammatory reactions are less severe with SMILE than with LASIK. ${ }^{69}$

As SMILE can only correct myopia and low degree astigmatism, and is only performed with one FS laser model, this technique is not yet widely employed by refractive surgeons..$^{70,71}$ Moreover, studies on this method have had short follow-up periods due to the recent advent of SMILE.

\section{FS laser-assisted cataract surgery}

The preferred method of removing cataracts in the developed world is phacoemulsification. However, the advent of FS lasers has changed cataract surgery profoundly. FS laserassisted cataract surgery (FLACS) includes creating manual corneal incisions and anterior capsulotomies, followed by phacoemulsification. ${ }^{72,73}$

There are actually five platforms for FS laser cataract surgery. They differ in image capturing, versatility, docking, lens fragmentation patterns, and speed of action, however they are technologically similar. The five platforms are: LenSX (Alcon LenSX, Inc., Aliso Viejo, CA, USA), LensAR (LENSAR, Inc., Winter Park, FL, USA), Catalys Precision Laser System (OptiMedica Corporation), VICTUS (Bausch \& Lomb Incorporated), and the FEMTO LDV Z (Ziemer Ophthalmic Systems). ${ }^{74}$

One intraoperative advantage of FLACS is a reduction of energy during phacoemulsification, as described by Abell et al, which can lead to a reduced corneal endothelium cell loss (common in standard phacoemulsification). ${ }^{75}$ Knorz reported a $25 \%$ decrease in endothelial cell loss in laser cases compared with manual cases at 1 month postoperatively. ${ }^{76}$

Some authors have suggested the benefits of FLACS over conventional cataract surgery include reproducibility of anterior capsulotomy and precision of corneal incision. ${ }^{77,78}$ Friedman et al reported a significant difference between FS laser and manual capsulorhexis with regard to the size and shape of the extracted capsule, with a mean deviation from centration of $77 \pm 47$ micrometers in the laser group. ${ }^{79}$ Nagy et al observed that FS laser capsulotomies were more regularly shaped and had improved centration and better intraocular lens/capsule overlap than manual capsulorhexes. ${ }^{80}$ These can lead to an expansion of the indications of refractive lens exchange and limbal-relaxing incisions, bringing the revolution not only to cataract surgery but also to the refractive surgery area.

Despite the good results, some complications have been reported in FLACS, such as suction breaks and capsular block syndrome. The failure in docking technique can also lead to tilting of the capsule and lens, incomplete capsulotomy, capsular tags, and secondary anterior capsule tear formation. ${ }^{81,82}$

FS laser uses less energy, causing less damage to the cornea than conventional surgery. The incisions in the cornea appear to be more stable and the capsulorhexis more precise than the manual technique, which favors higher optical quality, and more accurate premium intraocular lens centration. In addition, low rates of complications are described in FS technology when compared to manual phacoemulsification. However, FS technology will not eliminate the need for modern phacoemulsification, as this is necessary to emulsify hard nuclei, and there is also the issue of higher cost than conventional surgery. ${ }^{83}$

\section{Glaucoma therapy}

The treatment of glaucoma, a progressive disease which generates irreversible loss, can also benefit from the use of the FS laser in the future. An experimental study has shown that the FS laser can be used to perform sclerotomy for glaucoma therapy. The laser can make extremely precise incisions with a smoother inner surface with less peak power density. ${ }^{84}$ Another paper describes methods for design and manufacturing of a micro-mechanical valve for a novel glaucoma implant. The implant is designed to drain aqueous humor from the anterior chamber of the eye into the suprachoroidal space in case of elevated intraocular pressure. In contrast to any existing glaucoma drainage device, the valve mechanism is located in the anterior chamber and, surrounded by aqueous humor, immune to fibrosis induced failure. ${ }^{85}$

Further studies are needed for the laser to become important in glaucoma therapy, but this seems to be a reality in the near future.

\section{Conclusion}

The FS laser offers a variety of new treatment possibilities in many fields of ophthalmic anterior segment surgery. With regard to surgical outcome and safety, the FS laser seems to have advantages over most mechanical devices. The role of FS laser in corneal surgery is already well established, however, its use in rock-hard cataracts is questionable and requires further evaluation. Currently, the most important factor limiting the dissemination of the FS laser is its high cost. As with any other technology, competition will likely bring down the cost of the equipment making the price per case less expensive. FS lasers hold great promise and their applications are continuing to evolve and expand in ophthalmology. 


\section{Disclosure}

The authors have no conflicts of interest to disclose.

\section{References}

1. Chung SH, Mazur E. Surgical applications of femtosecond laser. J Biophotonics. 2009;2(10):557-572.

2. Ratkay-Traub I, Juhasz T, Horvath C, et al. Ultra-short pulse (femtosecond) laser surgery: initial use in LASIK flap creation. Ophthalmol Clin North Am. 2001;14(2):347-355.

3. Binder PS. Femtosecond applications for anterior segment surgery. Eye Contact Lens. 2010;36(5):282-285.

4. Hjortdal J, Nielsen E, Vestergaard A, Søndergaard A. Inverse cutting of posterior lamellar corneal grafts by a femtosecond laser. Open Ophthalmol J. 2012;6:19-22.

5. Ratkay-Traub I, Ferincz IE, Juhasz T, Kurtz RM, Krueger RR. First clinical results with the femtosecond neodymium-glass laser in refractive surgery. J Refract Surg. 2003;19(2):94-103.

6. Martin, AI, Hodge C, Lawless M, Roberts T, Sutton G. Femtosecond laser cataract surgery: Challenging cases. Current Opinion in Ophthalmology. 2014;25(1):71-80.

7. Piñero DP, Alio JL, El Kady B, et al. Refractive and aberrometric outcomes of intracorneal ring segments for keratoconus: mechanical versus femtosecond-assisted procedures. Ophthalmology. 2009; 116(9):1675-1687.

8. Farid M, Kim M, Steinert RF. Results of penetrating keratoplasty performed with a femtosecond laser zigzag incision initial report. Ophthalmology. 2007;114(12):2208-2212.

9. Por YM, Cheng JY, Parthasarathy A, Mehta JS, Tan DT. Outcomes of femtosecond laser-assisted penetrating keratoplasty. Am J Ophthalmol. 2008;145(5):772-774.

10. Sekundo W, Kunert K, Russmann C, et al. First efficacy and safety study of femtosecond lenticule extraction for the correction of myopia six-month results. J Cataract Refract Surg. 2008;34(9):1513-1520.

11. Holzer MP, Mannsfeld A, Ehmer A, Auffarth GU. Early outcomes of INTRACOR femtosecond laser treatment for presbyopia. $J$ Refract Surg. 2009;25(10):855-861.

12. Nubile M, Carpineto P, Lanzini M, et al. Femtosecond laser arcuate keratotomy for the correction of high astigmatism after keratoplasty. Ophthalmology. 2009;116(6):1083-1092.

13. Nagy Z, Takacs A, Filkorn T, Sarayba M. Initial clinical evaluation of an intraocular femtosecond laser in cataract surgery. $J$ Refract Surg. 2009;25(12):1053-1060

14. Tackman RN, Kuri JV, Nichamin LD, Edwards K. Anterior capsulotomy with an ultrashort-pulse laser. J Cataract Refract Surg. 2011;37(5): 819-824

15. Friedman NJ, Palanker DV, Schuele G, et al. Femtosecond laser capsulotomy. J Cataract Refract Surg. 2011;37(7):1189-1198.

16. Filkorn T, Kovács I, Takács A, Horváth E, Knorz MC, Nagy ZZ. Comparison of IOL power calculation and refractive outcome after laser refractive cataract surgery with a femtosecond laser versus conventional phacoemulsification. J Refract Surg. 2012;28(8):540-544.

17. Nagy ZZ. New technology update: femtosecond laser in cataract surgery. Clin Ophthalmol. 2014;8:1157-1167.

18. Sugar A, Rapuano CJ, Culbertson WW, et al. Laser in situ keratomileusis for myopia and astigmatism: safety and efficacy: a report by the American Academy of Ophthalmology. Ophthalmology. 2002;109(1): 175-187.

19. Stulting RD, Carr JD, Thompson KP, Waring GO 3rd, Wiley WM, Walker JG. Complications of laser in situ keratomileusis for the correction of myopia. Ophthalmology. 1999;106(1):13-20.

20. Talamo JH, Meltzer J, Gardner J. Reproducibility of flap thickness with IntraLase FS and Moria LSK-1 and M2 microkeratomes. J Refract Surg. 2006;22(6):556-561.

21. Slade SG. The use of the femtosecond laser in the customization of corneal flaps in laser in situ keratomileusis. Curr Opin Ophthalmol. 2007;18(4):314-317.
22. Rocha KM, Randleman JB, Stulting RD. Analysis of microkeratome thin flap architecture using Fourier-domain optical coherence tomography. $J$ Refract Surg. 2011;27(10):759-763.

23. Sutton G, Hodge C. Accuracy and precision of LASIK flap thickness using the IntraLase femtosecond laser in 1000 consecutive cases. J Refract Surg. 2008;24(8):802-806.

24. Stahl JE, Durrie DS, Schwendeman FJ, Boghossian AJ. Anterior segment OCT analysis of thin IntraLase femtosecond flaps. J Refract Surg. 2007;23(6):555-558.

25. Kezirian GM, Stonecipher KG. Comparison of the IntraLase femtosecond laser and mechanical keratomes for laser in situ keratomileusis. J Cataract Refract Surg. 2004;30(4):804-811.

26. Durrie DS, Kezirian GM. Femtosecond laser versus mechanical microkeratome flaps in wavefront-guided laser in situ keratomileusis: prospective contralateral eye study. J Cataract Refract Surg. 2005; 31(1):120-126.

27. Hamilton DR, Johnson RD, Lee N, Bourla N. Differences in the corneal biomechanical effects of surface ablation compared with laser in situ keratomileusis using a microkeratome or femtosecond laser. J Cataract Refract Surg. 2008;34(12):2049-2056.

28. Santhiago MR, Smadja D, Gomes BF, et al. Association between the percent tissue altered and post-laser in situ keratomileusis ectasia in eyes with normal preoperative topography. Am J Ophthalmol. 2014; 158(1):87-95.

29. Chen S, Feng Y, Stojanovic A, Jankov MR 2nd, Wang Q. IntraLase femtosecond laser vs mechanical microkeratomes in LASIK for myopia: a systematic review and meta-analysis. J Refract Surg. 2012; 28(1):15-24.

30. Colin J, Cochener B, Savary G, Malet F. Correcting keratoconus with intracorneal rings. J Cataract Refract Surg. 2000;26(8):1117-1122.

31. Alio JL, Shabayek MH, Artola A. Intracorneal ring segments for keratoconus correction: long-term follow-up. J Cataract Refract Surg. 2006;32(6):978-985.

32. Burris TE, Ayer CT, Evensen DA, Davenport JM. Effects of intrastromal corneal ring size and thickness on corneal flattening in human eyes. Refract Corneal Surg. 1991;7(1):46-50.

33. Ruckhofer J, Stoiber J, Alzner E, Grabner G; Multicenter European Corneal Correction Assessment Study Group. One-year results of European Multicenter Study of intrastromal corneal ring segments. Part 2: complications, visual symptoms, and patient satisfaction. J Cataract Refract Surg. 2001;27(2):287-296.

34. Kanellopoulos AJ, Pe LH, Perry HD, Donnenfeld ED. Modified intracorneal ring segment implantations (INTACS) for the management of moderate to advanced keratoconus: efficacy and complications. Cornea. 2006;25(1):29-33.

35. Bourcier T, Borderie V, Laroche L. Late bacterial keratitis after implantation of intrastromal corneal ring segments. $J$ Cataract Refract Surg. 2003;29(2):407-409.

36. Kubaloglu A, Sari ES, Cinar Y, et al. Comparison of mechanical and femtosecond laser tunnel creation for intrastromal corneal ring segment implant in keratoconus: prospective randomized clinical trial. J Cataract Refract Surg. 2010;36(9):1556-1561.

37. Rabinowitz YS, Li X, Ignacio TS, Maguen E. INTACS inserts using the femtosecond laser compared to the mechanical spreader in the treatment of keratoconus. J Refract Surg. 2006;22(8):764-771.

38. Carrasquillo KG, Rand J, Talamo JH. Intacs for keratoconus and postLASIK ectasia: mechanical versus femtosecond laser-assisted channel creation. Cornea. 2007;26(8):956-962.

39. Pinero DP, Alio JL. Intracorneal ring segments in ectatic corneal diseasea review. Clin Experiment Ophthalmol. 2010;38(2):154-167.

40. Coskunseven E, Jankov MR 2nd, Hafezi F, Atun S, Arslan E, Kymionis GD. Effect of treatment sequence in combined intrastromal corneal rings and corneal collagen crosslinking for keratoconus. J Cataract Refract Surg. 2009;35(12):2084-2091.

41. Kılı̧ A, Kamburoglu G, Akıncı A. Riboflavin injection into the corneal channel for combined collagen crosslinking and intrastromal corneal ring segment implantation. J Cataract Refract Surg. 2012;38(5):878-883. 
42. Sugar A. Ultrafast (femtosecond) laser refractive surgery. Curr Opin Ophthalmol. 2002;13(4):246-249.

43. Werner LP, Werner L, Pandey SK, Apple D. Physiology of accommodation and presbyopia. In: Agarwal A, editor. Presbyopia: A Surgical Textbook. Thorofare, NJ: Slack Incorporated; 2002:29-60.

44. Hosny M, El-Mayah E, Sidky MK, Anis M. Femtosecond laser-assisted implantation of complete versus incomplete rings for keratoconus treatment. Clin Ophthalmol. 2015;9:121-127.

45. Mulet ME, Alio JL, Knorz MC. Hydrogel intracorneal inlays for the correction of hyperopia: outcomes and complications after 5 years of follow-up. Ophthalmology. 2009;116(8):1455-1460.

46. Seyeddain O, Riha W, Hohensinn M, Nix G, Dexl AK, Grabner G. Refractive surgical correction of presbyopia with the AcuFocus small aperture corneal inlay: two-year follow-up. J Refract Surg. 2010;26(10): $707-715$.

47. Binder PS. New femtosecond laser software technology to create intrastromal pockets for corneal inlays. ARVO. 2010;51:2868.

48. Ruiz LA, Cepeda LM, Fuentes VC. Intrastromal correction of presbyopia using a femtosecond laser system. J Refract Surg. 2009;25(10): 847-854.

49. Holzer MP, Knorz MC, Tomalla M, Neuhann TM, Auffarth GU. Intrastromal femtosecond laser presbyopia correction: 1-year results of a multicenter study. J Refract Surg. 2012;28(3):182-188.

50. Yilmaz OF, Alagoz N, Pekel G, et al. Intracorneal inlay to correct presbyopia: long-term results. J Cataract Refract Surg. 2011;37(7): $1275-1281$.

51. Abbey A, Ide T, Kymionis GD, Yoo SH. Femtosecond laser-assisted astigmatic keratotomy in naturally occurring high astigmatism. Br J Ophthalmol. 2009;93(12):1566-1569.

52. Buzzonetti L, Petrocelli G, Laborante A, Mazzilli E, Gaspari M, Valente P. Arcuate keratotomy for high postoperative keratoplasty astigmatism performed with the IntraLase femtosecond laser. $J$ Refract Surg. 2009;25(8):709-714.

53. Alió JL, Javaloy J, Osman AA, Galvis V, Tello A, Haroun HE. Laser in situ keratomileusis to correct post-keratoplasty astigmatism; 1-step versus 2-step procedure. J Cataract Refract Surg. 2004;30(11): 2303-2310.

54. Pedrotti E, Sbado A, Marchini G. Customized transepithelial photorefractive keratectomy for iatrogenic ametropia after penetrating or deep lamellar keratoplasty. J Cataract Refract Surg. 2006;32(8): $1288-1291$.

55. Bochmann F, Schipper I. Correction of post-keratoplasty astigmatism with keratotomies in the host cornea. J Cataract Refract Surg. 2006;32(6):923-928.

56. Auffarth GU, Reddy KP, Ritter R, Holzer MP, Rabsilber TM. Comparison of the maximum applicable stretch force after femtosecond laser-assisted and manual anterior capsulotomy. $J$ Cataract Refract Surg. 2013;39(1):105-109.

57. Hoffart L, Proust H, Matonti F, Conrath J, Ridings B. Correction of postkeratoplasty astigmatism by femtosecond laser compared with mechanized astigmatic keratotomy. Am J Ophthalmol. 2009;147(5): 779-787.

58. Yoo SH, Kymionis GD, Ide T, Diakonis VF. Overcorrection after femtosecond assisted astigmatic keratotomy in a post-Descemet-stripping automated endothelial keratoplasty patient. J Cataract Refractive Surg. 2009;35(10): 1833-1834.

59. Shousha MA, Yoo SH. New therapeutic modalities in femtosecond laser-assisted corneal surgery. Int Ophthalmol Clin. 2010;50(3): 149-160.

60. Hoffart L, Proust H, Matonti F, Catanese M, Conrath J, Ridings B. Keratoplasties lamellaire anterieure assistee par laser femtoseconde. [Lamellar keratoplasty anterior assisted by femtosecond laser]. J Fr Ophthalmol. 2007;30:689-694. French.

61. Xia LK, Yu J, Chai GR, Wang D, Li Y. Comparison of the femtosecond laser and mechanical microkeratome for flap cutting in LASIK. Int $J$ Ophthalmol. 2015;8(4):784-790.
62. Price FW Jr, Price MO, Grandin JC, Kwon R. Deep anterior lamellar keratoplasty with femtosecond-laser zigzag incisions. J Cataract Refract Surg. 2009;35(5):804-808

63. Birnbaum F, Wiggermann A, Maier PC, Bohringer D, Reinhard T. Clinical results of 123 femtosecond laser-assisted penetrating keratoplasties. Graefes Arch Clin Exp Ophthalmol. 2013;251(1):95-103.

64. Hosny M. Common complications of deep lamellar keratoplasty in the early phase of the learning curve. Clin Ophthalmology. 2011;5: 791-795.

65. Alio JL, Abdelghany AA, Barraquer R, Hammouda LM, Sabry AM. Femtosecond Laser Assisted Deep Anterior Lamellar Keratoplasty Outcomes and Healing Patterns Compared to Manual Technique. Biomed Res Int. 2015;2015:397891

66. Alio JL, Vega A, Soria F, editors. Femtosecond Laser Assisted Keratoplasty. Jaypee Brothers Medical Pub; 2013.

67. Sekundo W, Kunert KS, Blum M. Small incision corneal refractive surgery using the small incision lenticule extraction (SMILE) procedure for the correction of myopia and myopic astigmatism: results of a 6 month prospective study. Brit J Ophthalmol. 2011;95(3):335-339.

68. Li M, Zhao J, Shen Y, et al. Comparison of dry eye and corneal sensitivity between small incision lenticule extraction and femtosecond LASIK for myopia. PLoS One. 2013;8(10):e77797.

69. Dong Z, Zhou X, Wu J, et al. Small incision lenticule extraction (SMILE) and femtosecond laser LASIK: comparison of corneal wound healing and inflammation. Br J Ophthalmol. 2014;98(2): 263-269

70. Trinh L, Denoyer A, Auclin F, Baudouin C. Femtosecond laserassisted cataract surgery. J Fr Ophtalmol. 2015;38(7):646-655.

71. Shah R, Shah S, Sengupta S. Results of small incision lenticule extraction: All-in-one femtosecond laser refractive surgery. J Cataract Refract Surg. 2011;37(1):127-137.

72. Uy HS, Edwards K, Curtis N. Femtosecond phacoemulsification: the business and the medicine. Curr Opin Ophthalmol. 2012; 23(1):33-39.

73. Hatch KM, Schultz T, Talamo JH, Dick HB. Femtosecond laser-assisted compared with standard cataract surgery for removal of advanced cataracts. J Cataract Refract Surg. 2015;41(9):1833-1838.

74. Alió JL, Abdou AA, Puente AA, Zato MA, Nagy Z. Femtosecond laser cataract surgery: updates on technologies and outcomes. J Refract Surg. 2014;30(6):420-427.

75. Abell RG, Kerr NM, Vote BJ. Femtosecond laser-assisted cataract surgery compared with conventional cataract surgery. Clin Experiment Ophthalmol. 2013;41(5):455-462.

76. Knorz MC. Reduction in mean cumulative dissipated energy following lens liquefaction with an intraocular femtosecond laser. Poster presented at: the American Academy of Ophthalmology Annual Meeting; October 22-25; 2011; Orlando, FL.

77. Masket S, Sarayba M, Ignacio T, Fram N. Femtosecond laser-assisted cataract incisions: architectural stability and reproducibility. J Cataract Refract Surg. 2010;36(6):1048-1049.

78. Kranitz K, Takacs A, Mihaltz K, Kovacs I, Knorz MC, Nagy ZZ. Femtosecond laser capsulotomy and manual continuous curvilinear capsulorrhexis parameters and their effects on intraocular lens centration. J Refract Surg. 2011;27(8):558-563.

79. Schweitzer C, Tellouck L, Gaboriau T, Leger F. Anterior capsule contraction treated by femtosecond laser capsulotomy. J Refract Surg. 2015;31(3):202-204.

80. Nagy Z, Kranitz K, Takacs AI, Mihaltz K, Kovacs I, Knorz MC. Comparison of intraocular lens decentration parameters after femtosecond and manual capsulotomies. J Refract Surg. 2011;27(8):564-569.

81. Roberts TV, Sutton G, Lawless MA, Jindal-Bali S, Hodge C. Capsular block syndrome associated with femtosecond laser-assisted cataract surgery. J Cataract Refract Surg. 2011;37(11):2068-2070.

82. Chen M, Swinney C, Chen M. Comparing the intraoperative complication rate of femtosecond laser-assisted cataract surgery to traditional phacoemulsification. Int J Ophthalmol. 2015;8(1):201-203. 
83. Alió JL. Cataract surgery with femtosecond lasers. Saudi J Ophthalmol. 2011;25(3):219-223.

84. Jin L, Jiang F, Dai N, et al. Sclerectomy with nanojoule energy level per pulse by femtosecond fiber laser in vitro. Opt Express. 2015; 23(17):22012-22023.
85. Siewert S, Schultze C, Schmidt W, et al. Development of a micro mechanical valve in a novel glaucoma implant. Biomed Microdevices. 2012;14(5):907-920.

\section{Publish your work in this journal}

Clinical Ophthalmology is an international, peer-reviewed journal covering all subspecialties within ophthalmology. Key topics include: Optometry; Visual science; Pharmacology and drug therapy in eye diseases; Basic Sciences; Primary and Secondary eye care; Patien Safety and Quality of Care Improvements. This journal is indexed on

Submit your manuscript here: http://www.dovepress.com/clinical-ophthalmology-journal

\section{Dovepress}

PubMed Central and CAS, and is the official journal of The Society of Clinical Ophthalmology (SCO). The manuscript management system is completely online and includes a very quick and fair peer-review system, which is all easy to use. Visit http://www.dovepress.com/ testimonials.php to read real quotes from published authors. 